\title{
PEMANFAATAN LIMBAH BIJI PARE SEBAGAI PUPUK KOMPOS PADA UKM SABILLAH PIDIA
}

\author{
Yuni Agung Nugroho ${ }^{1^{*}}$, Aria Wastra Boja ${ }^{2}$, Raka Aryatama Akhmadi ${ }^{3}$, Honggo \\ Sumarsono ${ }^{4}$, Tanya Putri Nadia $^{5}$ \\ ${ }^{1}$ Program Studi Agroteknologi, Fakultas Pertanian, Universitas Widyagama \\ ${ }^{4}$ Program Studi Agribisnis, Fakultas Pertanian, Universitas Widyagama \\ 2,3,5 Program Studi Akuntansi, Fakultas Ekonomi dan Bisnis, Universitas Widyagama \\ *Email Korespondensi: agung@widyagama.ac.id
}

Submitted : 16 September 2021; Revision : 20 September 2021; Accepted : 8 Oktober 2021

\begin{abstract}
ABSTRAK
Perkembangnya sektor pertanian berdampak pada peningkatan kebutuhan semua sarana pertanian, termasuk pupuk. Harga pupuk kimia (biasanya pupuk anorganik) seringkali naik sehingga menjadi kurang terjangkau bagi petani, hal ini sering diikuti dengan tidak adanya ketersediaan pupuk yang cukup. Padahal tanaman membutuhkan nutrisi yang cukup untuk tumbuh. Nutrisi yang dibutuhkan tanaman terdapat dalam bentuk unsur hara di dalam tanah. Pemupukan dilakukan untuk menambah ketersediaan unsur hara di dalam tanah. Karena pupuk mempunyai peran penting bagi pertumbuhan tanaman, sehingga kelompok 6 Kuliah Pengabdian Masyarakat Universitas Widyagama Malang pada tahun 2021 periode kedua, memilih mengadakan pelatihan produksi pupuk organik dari limbah biji pare. Manfaat kompos atau pupuk organik adalah untuk memperbaiki kesuburan tanah secara kimia, fisika dan biologi dengan cara meningkatkan bahan organik tanah.
\end{abstract}

Kata kunci : Kompos; Organik; Pupuk; Biji Pare

\section{ABSTRACT}

The development of the agricultural sector has an impact on increasing the need for all agricultural facilities, including fertilizers. The price of chemical fertilizers (usually inorganic fertilizers) often rises so that it becomes less affordable for farmers, this is often followed by the absence of sufficient fertilizer availability. Though plants need sufficient nutrients to grow. Nutrients needed by plants are found in the form of nutrients in the soil. Fertilization is done to increase the availability of nutrients in the soil. Because fertilizer has an important role for plant growth, group 6 of the Widyagama Malang University Community Service Lecture in 2021 for the second period, chose to hold training on the production of organic fertilizer from bitter melon seed waste. The benefit of compost or organic fertilizer is to improve soil fertility chemically, physically and biologically by increasing soil organic matter.

Keywords : Compost; Organic; Fertilizer; Bitter Melon Seeds

\section{PENDAHULUAN}

Sampah adalah material sisa yang tidak diinginkan setelah berakhirnya suatu proses. Umumnya sampah berasal dari kegiatan yang dilakukan oleh manusia (termasuk kegiatan industri), namun bisa juga berupa sampah organik dan umumnya bersifat padat. Sampah erat kaitannya dengan kesehatan masyarakat, karena dari sampah tersebut akan hidup berbagai mikroorganisme penyebab penyakit (Bacteri pathogen), dan juga binatang serangga pemindah atau penyebar penyakit (Notoatmodjo, 2007).

Sampah di Indonesia merupakan masalah yang kompleks karena kurangnya pemahaman masyarakat tentang dampak sampah dan kurangnya dana untuk mengupayakan pengolahan sampah yang layak dan berkualitas. Faktor lain yang memperumit masalah sampah Indonesia adalah peningkatan taraf hidup masyarakat. Hal 
ini merupakan ketidakkonsistenan pengetahuan tentang sampah dan kurangnya partisipasi masyarakat untuk menjaga kebersihan dan menempatkan sampah pada tempatnya (Sumantri, 2017).

Pare adalah sejenis tumbuhan merambat dengan buah yang panjang danruncing pada ujungnya serta permukaan bergerigi. Pare tumbuh baik di dataran rendah dan dapat ditemukan tumbuh liar di tanah telantar, tegalan, dibudidayakan, atau ditanam di pekarangan dengan dirambatkan di pagar. Tanaman ini tumbuh merambat atau memanjat dengan sulur berbentuk spiral, banyak bercabang, berbau tidak enak serta batangnya berusuk isma. Rasa pare cenderung pahit tetapi di jaman sekarang pare dapat diolah menjadi berbagai macam produk dari kesehatan, kecantikan sampai makanan. Meskipun rasa pare pahit, ternyata terdapat segudang manfaat. Antara lain melancarkan pencernaan, mengatasi sembelit, menjaga berat badan dan mencegah obesitas, mengatasi diabetes, membantu memerangi virus hiv/aids. meningkatkan kesehatan mata, mengobati panas dalam, mengatasi jerawat, meningkatkan kekebalan tubuh, mencegah stroke dan penyakit jantung, menurunkan tekanan darah tinggi, membersihkan sirkulasi darah dan masih banyak lagi. Pare juga dapat diolah menjadi makanan enak yaitu kripik pare. Kripik pare merupakan sebuah inovasi dimana cara menikmati pare agar tidak terasa pahit saat dimakan. Di daerah Malang terdapat udaha pembuatan kripik pare. Nama usahanya adalah Sabillah Pidia. Usaha ini menggunakan pare sebagai bahan utama untuk membuat kripik. Tetapi sayangnya dari pengolahan ini terdapat limbah yang langsung dibuang begitu saja. Limbah itu berupa isian dari pare. Kurangnya pengetahuan untuk mengolah limbah dan alat yang terbatas menjadi permasalahan bagi pemilik usaha.

Pengolahan sampah organik telah lama dilakukan, termasuk pemanfaatan sampah organik dalam pakan ternak. Selama ini daur ulang sampah ini kurang bersih dan menimbulkan masalah kesehatan. Permasalahnya timbul bukan pada pengembangan sistem daur ulang, tetapi bagaimana membuat daur ulang sampah menjadi lebih efisien dan dapat digunakan dengan cara yang lebih higienis. Salah satu cara untuk mengatasi masalah daur ulang sampah organik secara lebih efisien adalah melakukan pengomposan (Firmansyah, 2010; Suhastyo, 2017).

Pengomposan adalah proses penguraian bahan organik atau penggunaan mikroorganisme untuk mengubah senyawa komplek menjadi senyawa sederhana. Kompos merupakan salah satu jenis pupuk organik yang sudah ada sejak lama. Pengertian kompos adalah bahan-bahan organik yang sudah mengalami proses pelapukan karena terjadi interaksi antara mikroorganisme pembusuk yang bekerja di dalam bahan organik tersebut. Bahan organik yang menjadi bahan kompos adalah rumput, jerami, kotoran hewan, daun tumbuhan yang rontok, serta bahan organik lainnya. Semua bahan organik tersebut akan mengalami pelapukan yang diakibatkan oleh mikroorganisme yang tumbuh subur pada lingkungan lembap dan basah. Kompos memiliki harga yang murah dan dapat digunakan sebagai pengganti pupuk. Kompos berfungsi untuk memperbaiki struktur tanah, tekstur, aerasi, dan meningkatkan daya serap air tanah. Kompos dapat mengurangi kepadatan tanah liat, membantu tanah berpasir mempertahankan kelembaban, dan kompos dapat menjadi stimulan untuk meningkatkan kesehatan akar tanaman. Hal ini dimungkinkan, selain fakta bahwa kompos dapat menyediakan makanan bagi mikroorganisme yang menjaga tanah tetap sehat dan seimbang, selain fakta bahwa mikroorganisme ini secara alami menghasilkan nitrogen dan fosfor dari proses konsumsi (Sulistyorini, 2005; Harlis et al., 2019).

Kompos mengandung unsur hara utama dan mikro, sehingga mengandung unsur hara yang cukup lengkap. Namun, jumlahnya relatif kecil dan tergantung pada bahan baku, proses pembuatan, aditif, kematangan dan metode penyimpanan. Namun, kualitas kompos dapat ditingkatkan dengan menambahkan mikroorganisme yang menguntungkan (Sulistyorini, 2005; Firmansyah, 2010; Suhastyo, 2017).

Berdasarkan penjelasan di atas, penulis tertarik untuk menggunakan residu pare sebagai bahan organik pada kompos. Hasil pemanfaatan sisa pare sebagai bahan organik 
untuk pembuatan kompos ini, diharapkan dapat menghasilkan metode yang sesuai dan berdampak positif baik dari segi ekonomi maupun kesehatan masyarakat khususnya dalam pengolahan sampah organik (Illa and Mukarlina, 2017; Ratna, Samudro and Sumiyati, 2017; Suwahyono, 2017; Harlis et al., 2019; Rao, 2021).

\section{METODE}

Metode yang digunakan adalah metode in-container. Sistem pengomposan in-fiber adalah sistem pengomposan yang terbuat dari tangki tertutup. Proses ini dilakukan secara mekanis untuk menghindari bau dari udara yang dimasukkan dan untuk memantau suhu dan konsentrasi oksigen. Langkah pertama dalam membuat kompos adalah pembuatan tempat kompos, prosedur pembuatan tempat kompos adalah sebagai berikut:

1. Masukkan wadah filter ke dalam ember, lalu masukkan filter.

2. Buat lubang di dasar ember sekitar $1-2 \mathrm{~cm}$ dari dasar ember dan pasang kran atau selang plastik sebagai lubang untuk mengalirkan lindi yang dihasilkan selama proses pengomposan.

3. Buat lubang di pelat plastik dengan paku atau paku panas (ini berfungsi sebagai filter).

4. Pasang keran atau selang ke lubang.

5. Kompos siap diisi dengan sampah daur ulang.

Adapun cara membuat kompos adalah sebagai berikut:

1. Memisahkan sampah organik (limbah pare/kandungan pare) dan sampah non-organik.

2. Potong sampah organik menjadi potongan-potongan kecil sekitar $1-2 \mathrm{~cm}$

3. Tambahkan sampah organik ke dalam kompos.

4. Anda dapat menambahkan sampah kompos sampai penuh.

5. Semprot sampah organik dengan bioaktivator (bisa menggunakan EM4) sampai rata.

6. Lakukan penyemprotan setiap kali memasukkan sampah dan tutup rapat kembali komposter.

7. Tutup kompos dengan rapat.

8. Diamkan selama \pm 14 hari agar terjadi proses pengomposan.

\section{HASIL DAN PEMBAHASAN}

\section{A. Hasil Pengomposan}

Dari proses pengomposan dilakukan pengukuran parameter suhu dan kelembaban bahan komposan setiap hari dengan mengamati kecepatan waktu proses composting hingga mendapat kompos dengan ciri-ciri fisik sebagai berikut :

1. Berwarna cokelat gelap hingga hitam

2. Berbau tanah

3. Berbintik serbuk putih

Pengamatan ini dibantu dengan menggunakan alat ukur seperti thermometer untuk mengukur suhu, dan hygrometer untuk mengukur kelembaban pupuk kompos.

\section{B. Hasil Pengamatan}

Setelah melakukan pengamatan kepada wadah perlakukan dan wadah kontrol dari hari pertama pembuatan pupuk kompos hingga hari keempat belas (dua minggu) maka diperoleh hasil pengamatan seperti pada Gambar 2-3. Pada Gambar 2 dapat dilihat grafik rata-rata suhu $\left({ }^{0} \mathrm{c}\right)$ per hari dalam pembuatan kompos sampah organik sisasisa limbah sayuran dengan aktifator biji pare selama 14 hari. Berdasarkan grafik tersebut bahwa volume 1 liter dan kontrol cenderung mengalami sedikit kenaikan hingga suhu $490 \mathrm{C}$, pada volume 2 liter mengalami kenaikan hingga $50{ }^{\circ} \mathrm{C}$, sedangkan pada volume 3 liter mengalami kenaikan hingga pada suhu $51^{\circ} \mathrm{C}$. Pada Gambar 3 
adalah grafik rata-rata kelembaban (\%) per hari dalam pembuatan kompos sampah organik sisa-sisa limbah sayuran dengan aktifator biji pare selama 14 hari. Berdasarkan grafik di atas volume 1 liter dan kontrol cenderung mengalami sedikit kenaikan yang menghasilkan kelembaban $50 \%$, sedangkan volume 2 liter dan 3 liter juga cenderung mengalami kenaikan hingga kelembaban $55 \%$ tetapi volume embio pengurai 2 liter dengan kelembaban tetap atau $50 \%$. Dokumentasi kegiatan pengabdian kepada masyarakat dapat dilihat pada Gambar 1.
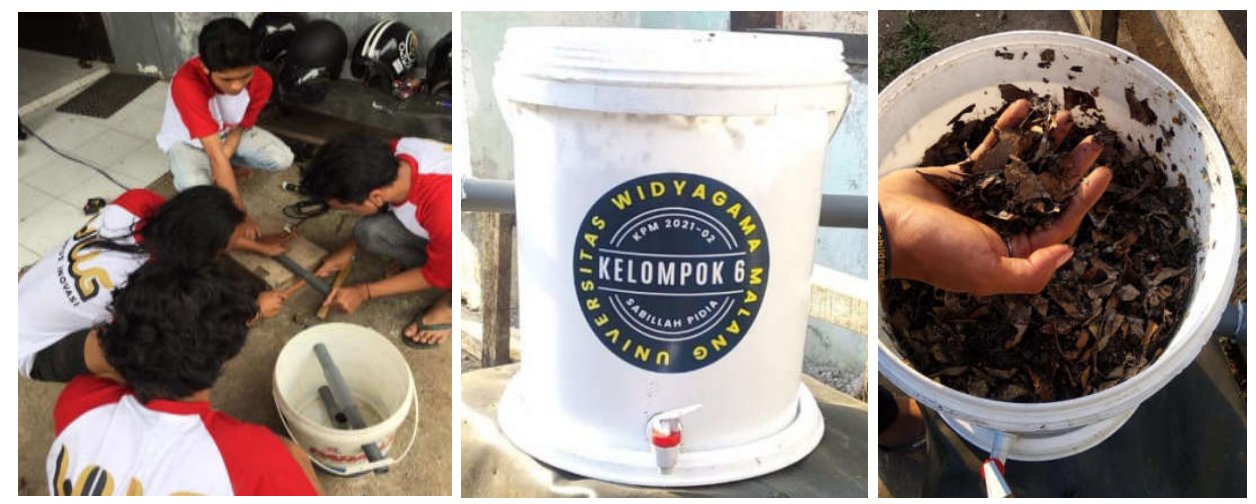

Gambar 1. Proses Pembuatan Kompos Menggunakan Limbah Pare

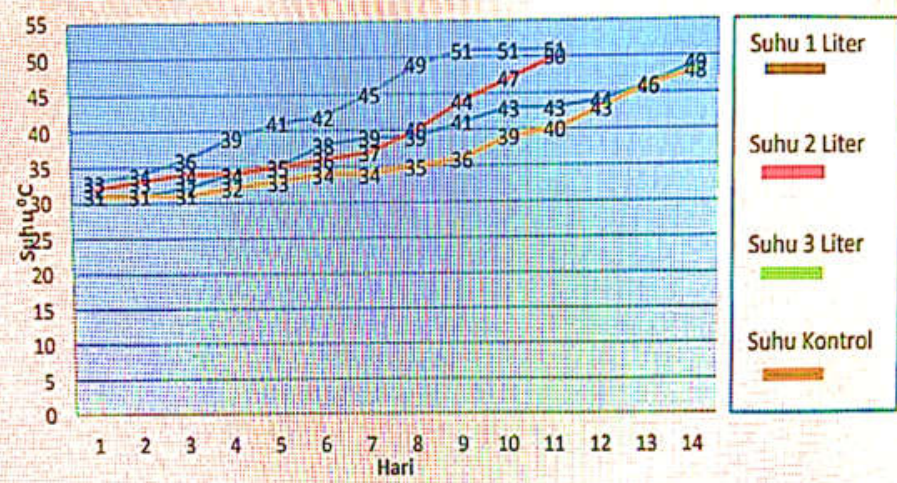

Gambar 2. Grafik Perubahan Suhu Setiap Hari

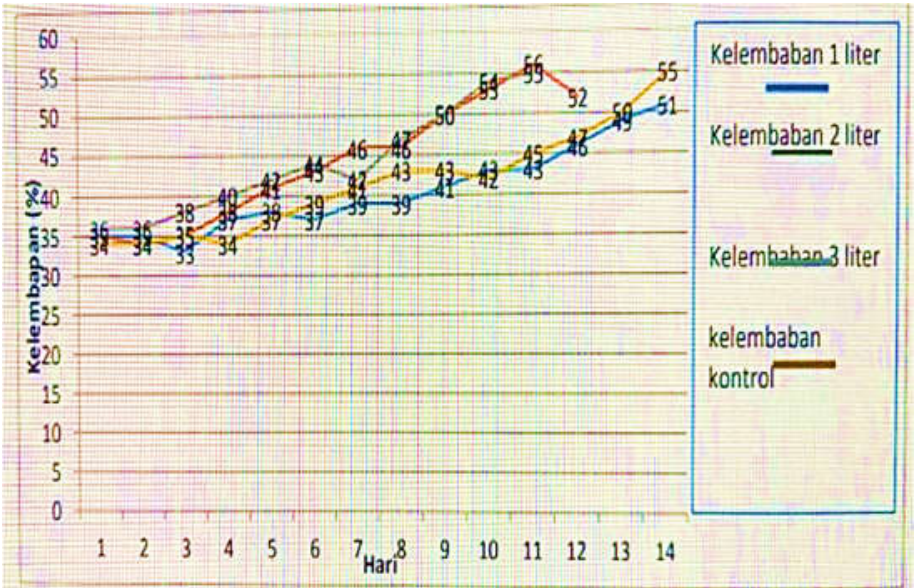

Gambar 3. Grafik Perubahan Kelembaban Setiap Hari 


\section{DAMPAK DAN MANFAAT}

Penggunaan pupuk organik memiliki banyak keuntungan untuk pemupukan lahan pertanian. Penekanan pada penggunaan pupuk organik secara terus menerus dan berkelanjutan memberikan manfaat dan manfaat untuk penggunaan jangka panjang.

1. Pupuk organik dapat berperan dalam memobilisasi atau mengikat unsur hara yang sudah ada di dalam tanah, sehingga memungkinkan terbentuknya partikel ionik yang mudah diserap oleh akar tanaman.

2. Pupuk organik berperan dalam melepaskan unsur hara secara perlahan dan terus menerus dari dalam tanah, mencegah timbulnya unsur hara yang dapat meracuni tanaman.

3. Pupuk organik membantu menjaga kelembaban tanah dan mengurangi stres pada akar tanaman dan struktur tanah.

4. Pemupukan organik cenderung membuat komposisi partikel tanah lebih stabil dan meningkat karena struktur tanah memainkan peran yang sangat penting dalam pergerakan partikel air dan udara di dalam tanah dan memberikan aktivitas mikroba yang menguntungkan, dalam arti dapat memperbaiki tanah. struktur.

5. Pupuk organik sangat membantu dalam mencegah pengikisan lapisan atas tanah yang banyak mengandung unsur hara.

6. Penggunaan pupuk organik juga berperan penting dalam mengelola/mempertahankan tingkat kesuburan pada tanah yang sudah dipupuk secara berlebihan dengan pupuk anorganik/kimia di dalam tanah.

7. Pupuk organik berperan aktif dalam mengurangi hilangnya unsur hara nitrogen dan fosfor terlarut di dalam tanah.

8. Pupuk organik menjaga kesuburan tanah yang lengkap yaitu kesuburantanah secara fisika, kimia, dan biologi. Hal ini menjamin penyediaan unsur hara yang diperlukan tanaman, membuat kondisi tanah menjadi lebih gembur dan tanah menjadi lebih sehat bagi pertumbuhan akar tanaman.

\section{KESIMPULAN}

Berdasarkan hasil aktifitas dan pengamatan di lapangan maka diambil kesimpulan bahwa biji pare yang diracik dengan tambahan bioaktifator (EM4 atau campuran air nenas dengan EM4) menjadi embio pengurai. Embrio pengurai dapat digunakan sebagai aktifator dalam pembuatan kompos. Pemanfaatan embrio pengurai akan mempercepat proses pengomposan pada sampah organik sisa sayuran rumah tangga. Perubahan suhu rata-rata dan kelembaban rata-rata pada proses pengomposan terjadi karena ada aktifitas fermentasi oleh mikroba pada bahan organik. Hal ini menunjukkan berjalannya proses pengomposan. Pemanfaatan air nenas yang diracik dengan EM4 (embio pengurai) sebagai aktifator pada pengolahan sampah organic sisa sayuran rumah tangga dalam pembuatan kompos perlu dimasyarakatkan, mengingat keberadaan embio pengurai mudah diperoleh dan dilakukan. Perlu dicoba pembuatan kompos dengan bahan organik yang lain. Bagi masyarakat/petani dapat menggunakan aktifator embio pengurai dalam pembuatan kompos, karena lebih mudah, sederhana dan ramah lingkungan.

\section{UCAPAN TERIMA KASIH}

Ucapan terima kasih disampaikan kepada Universitas Widyagama Malang, yang telah meyelenggarakan Kuliah Pengabdian Kepada Masyarakat, UKM Sabillah Pidia yang telah bersedia menjadi mitra pengabdian masyarakat, dan semua anggota kelompok 6 Kuliah Pengabdian Masyarakat tahun 2021-2. 


\section{REFERENSI}

Firmansyah, M.A. (2010) 'Teknik Pembuatan Kompos', Pelatihan Petani Plasma Kelapa Sawit di Kabupaten Sukamara, Kalimantan Tengah.

Harlis, H. et al. (2019) 'Pelatihan Pembuatan Kompos Organik Metode Keranjang Takakura sebagai Solusi Penanganan Sampah di Lingkungan Kost Mahasiswa', DEDIKASI: Jurnal Pengabdian Masyarakat, 1(1), pp. 1-8.

Illa, M. and Mukarlina, R. (2017) 'Pertumbuhan Tanaman Pakchoy (Brassica chinensis L.) pada Tanah Gambut dengan Pemberian Pupuk Kompos Kotoran Kambing', Protobiont, 6(3).

Notoatmodjo, S. (2007) 'Promosi Kesehatan dan Ilmu Perilaku', Rineka Cipta.

Rao, T.A.P.D. (2021) 'Respon Pemberian Pupuk Organik Cair Dari Cangkang Telur Dan Air Rebusan Kedelai Untuk Pertumbuhan Dan Produksi Tanaman Pare (Mormodicha charantia L.)', Kumpulan Karya Ilmiah Mahasiswa Fakultas sains dan Tekhnologi, 2(2), pp. 26-26.

Ratna, D.A.P., Samudro, G. and Sumiyati, S. (2017) 'Pengaruh Kadar Air Terhadap Proses Pengomposan Sampah Organik Dengan Metode Takakura', Teknik Mesin, 6, pp. 124-128.

Suhastyo, A.A. (2017) 'Pemberdayaan Masyarakat Melalui Pelatihan Pembuatan Pupuk Kompos', JPPM (Jurnal Pengabdian dan Pemberdayaan Masyarakat), 1(2), pp. 63-68.

Sulistyorini, L. (2005) 'Pengelolaan Sampah Dengan Cara Menjadikannya Kompos', Jurnal Kesehatan Lingkungan, 2(1).

Sumantri, H.A. (2017) Kesehatan Lingkungan-Edisi Revisi. Prenada Media.

Suwahyono, U. (2017) Panduan Penggunaan Pupuk Organik. Penebar Swadaya. 